\title{
PENERAPAN METODE SCRAMBLE DALAM PEMBELAJARAN PENDIDIKAN AGAMA KRISTEN UNTUK MENINGKATKAN HASIL BELAJAR SISWA
}

\author{
Agnes Monica Halawa \\ SD Tunas Cemerlang Jakarta Timur \\ (Alumni Prodi Magister Pendidikan Agama Kristen, Universitas Kristen Indonesia) \\ halawaagnes@gmail.com
}

\begin{abstract}
Abstrak
Dalam proses pembelajaran guru sangat memerlukan metode sebagai sarana, teknik untuk penyampaian materi dan mencapai tujuan pembelajaran itu sendiri. Metode scramble salah satu metode pembelajaran yang menarik untuk diterapkan dalam proses pembelajaran khususnya pendidikan agama Kristen karena membantu konsentrasi dan kecepatan berpikir siswa dalam belajar.Tujuan dari penelitian ini dengan penerapan metode scramble peneliti ingin meningkatkan hasil belajar siswa pada mata pelajaran pendidikan agama kristen di SD Tunas Cemerlang, Jakarta Timur dengan jumlah 10 siswa Kristen diantaranya ada 4 siswa perempuan dan 6 siswa lakilaki. Pada penelitian ini peneliti menggunakan metode penelitian Tindakan Kelas (PTK) atau classroom action research, data hasil penelitian diperoleh berdasarkan hasil observasi nilai akhir semester siswa yang dilakukan dengan dua kali siklus dalam satu tahun pembelajaran atau satu siklus persemester.Dalam setiap siklus pada penelitian ini dilakukan dengan 4 langkah yaitu perencanaan, pelaksanaan, observasi atau pengamatan dan refleksi atau evaluasi. Penerapan metode scramble untuk peningkatan hasil belajar siswa dalam pembelajaran pendidikan agama Kristen diperoleh data hasil siklus I 50\% siswa mampu berhasil mencapai hasil belajar yang sesuai dengan kriteria ketuntasan minimum dan data pada siklus II terlihat peningkatan dengan hasil $80 \%$ siswa berhasil mencapai hasil belajar di atas kriteria ketuntasan minimum di mata pelajaran pendidikan agama Kristen. Penerapan metode scramble dapat di terapkan dalam pembelajaran pendidikan agama Kristen untuk mencapai tujuan penelitian ini dalam meningkatkan hasil belajar, selain itu juga membantu meningkatkan aktivitas guru dan aktivitas siswa. Metode scramble juga membantu proses pembelajaran pendidikan agama Kristen menjadi tidak membosankan.
\end{abstract}

Kata Kunci: Metode Scramble, Hasil Belajar, Pendidikan Agama Kristen

\begin{abstract}
In the learning process the teacher needs a method as a means, a technique for conveying material and achieving the learning objectives itself. The scramble method is on of interesting learning methods to be applied in the learning process, especially for Christian religious education because it helps concentration and thinking speed of student in learning. The purpose of this study by applying the scramble method is the researcher wanted to improve learning outcomes of student in Christian religious education at Tunas Cemerlang primary school, East Jakarta with a total of 10 christian students consisting of 4 female students and 6 male students. The method
\end{abstract}


used in this research is classroom action research (PTK) carried out in two cycles in one learning year or one cycle in one semester. In each cycle consisting of four stages, namely planning, implementing, observing, and reflecting. The application of the scramble method to improve student learning outcomes in Christian religious education resulted in cycle I (50\%) students were able to successfully achieve learning outcomes in according with the minimum completenees criteria and cycle II showed an increase with the results of (80\%) students successfully achieving learning outcomes above the minimum completeness criteria in chirstian religious education subjects. The application of the scramble method can done in Christian religious education learning to achieve the objectives of this study in improving learning outcomes, but also helping to increase activity of teacher and student activity. The scramble method also helps the learning process of Christian religious education to be not boring.

Keywords :Scramble Method, Learning Outcomes, Chirstian Religious Education

\section{Pendahuluan}

Pendidikan merupakan bagian penting yang harus diberikan kepada anak dan tidak bisa terpisah dari kehidupan setiap manusia. Pendidikan itu sendiri di atur dalam UUD RI 1945 pasal $28 \mathrm{c}$ ayat (1) yang berisi dan menjelaskan tentang hak setiap orang untuk dapat merasakan dan memperoleh pendidikan serta manfaat dari ilmu pengetahuan dan teknologi, seni dan budaya. ${ }^{1}$ Pendidikan yang diberikan kepada anak bukan hanya berisi pembelajaran tentang sains atau matematika, akan tetapi anak juga perlu untuk memperoleh pembelajaran agama kristen dalamkehidupannya.

Dalam masa pembelajaran yang diterima anak disekolah, anak akan memperoleh hasil akhir pencapaian dari pelajar yang diterimamelalui berbagai tes dan ujian yang dilaksanakan oleh sekolah.Hasil akhir atau hasil belajar merupakan gambaran dari pencapain, pemahaman anak dalam menerima materi atau pembelajaran selama satu

\footnotetext{
${ }^{1}$ Heri Herdiawanto, Fokky Fuad Wasitaatmadja, dan Jumanta Hamdayama, Kewarganegaraan dan Masyarakat Madani (Jakarta: Prenadamedia Group, 2019), 147.
}

semester.Sejalan dengan pendapat Sudjana yang mengatakan bahwa hasil belajar adalah hak setiap orang untuk memperoleh perubahan tingkah laku, dalam hal perubahan ini mencakup bidang kognitif, afektif, dan psikomotorik. $^{2} \quad$ Keberhasilan pembelajaran diterima siswa akan terlihat dari hasil akhir atau hasil belajar yang diterima dengan mencapai standar kompetensi atau kompetensi kelulusan minimalyang sudah ditetapkan.

Dalam dunia pendidikan mencapai hasil belajar yang terbaik adalah tujuan atau tolak ukur dari keberhasilan guru menyampaikan dan mengajar materi ajar kepada siswa dengan berbagai metode yang digunakan.Hasil belajar juga merupakan sebagai tanda bahwa siswa mampu memahami pembelajaran yang diberikan, selain itu hasil belajar yang terbaik merupakan harapan yang diinginkan oleh siswa dan juga orangtua selama anak menuntut ilmu.

Namun jika melihat dalam kenyataanya masih banyak siswa yang

\footnotetext{
${ }^{2}$ Edy Syahputra, Snowbal Throwing Tingkatkan Minat dan Hasil Belajar (Sukabumi: Haura Publising, 2020), 24.
} 
menerima hasil belajar yang tidak mencapai standar minimal kompetensi atau standar kompetensi kelulusan yang telah ditentukan.Salah satu faktor yang menyebabkan hasil belajar siswa rendah ialah dari internal dalam diri siswa itu sendiri yang merasa jenuh, bosan dan kurang konsetrasi dan banyaknya siswa yang pasif selama proses pembelajaran agama Kristen berlangsung. Faktor lain adalah faktor eksternal yaitu metode pembelajaran yang digunakan guru kurang menarik sehingga membuat siswa menjadi merasakan kebosanan dan tidak bisa berkonsentrasi dalam menerima materi belajar yang disampaikan dan pembelajaran hanya terpusat kepada guru.

Rendahnya hasil belajar siswa juga terlihat pada siswa kelas 5-6 di SD Tunas Cemerlang, Jakarta Timur dalam pembelajaran Pendidikan Agama Kristen. Selain masalah di atas, salah satu masalah yang paling mendasar adalah SD Tunas Cemerlang ini sebelumnya belum memiliki guru khusus dibidang pendidikan agama Kristen selama kurang lebih 2 tahun, hal ini menyebabkan kurangnya pemahaman siswa tentang pembelajaran pendidikan agama Kristen, awalnya siswa hanya memahami bahwa pendidikan agama Kristen adalah pelajaran yang hanya mempelajari tentang pembacaan Alkitab saja dan hasil nilai yang diperoleh hanya berdasarkan pemahaman mengenal alkitab dan hanya dari hasil lembar tugas. Dalam pembelajaran pendidikan agama Kristen yang awalnya tidak ada guru khusus dibidang studi dan hanya di damping oleh guru yang beragama Kristen, selama proses pembelajaran guru hanya mendampingi siswa untuk pembacaan alkitab, mengerjakan lembar tugas tanpa ada yang menjelaskan dan mengarahkan siswa secara detail tentang materi pendidikan agama Kristen.Untuk meningkatkan hasil belajar siswa dibutuhkan metode pembelajaran yang efektif, kreatif dan menyenangkan bagi siswa dalam menerima materi ajar. Selaras dengan masalah di atas N.M.Putri Saridewi mengatakan bahwa upaya untuk mengatasi suatu masalah yang umum yang terjadi diperlukan suatu metode yang meningkatkan keaktivan siswa yang akanberpengaruh pada hasil belajar siswa. Salah satu metode yang bisa diterapkan untuk meningkatkan hasil belajar siswa menurut N.M. Putri Saridewi ialah metode scramble yang mana metode ini bersifat aktif dan salah satu strategi pembelajaran yang motivasional yang mampu meningkatkan motivasi dan prestasi belajar siswa. ${ }^{3}$

Melihat kondisi penjelasan dan agar terlaksananya belajar mengajar pada pembelajaran pendidikan agama Kristen di SD tersebut maka penulis melakukan inovasi metode dalam pembelajaran pendidikan agama Kristen untuk meningkatkan hasil belajar siswa.Metode pembelajaran yang bisa digunakan yaitu metode scramble yang mana metode scramble merupakan metode belajar yang bisa membantu untuk meningkatkan konsetrasi dan berpikir siswa. ${ }^{4}$ Pemilihan metode dapat dijadikan sebagai cara baru dan menarik siswa dalam menentukan pencapaian hasil belajar. Dengan penggunaan metode belajar scramble yang baru khususnya dalam pendidikan agama Kristen guru bisa menyampaikan materi dan diterima dengan baik oleh

\footnotetext{
${ }^{3}$ N.M. Putri Saridewi dan N.Nym. Kusmariyatni, "Penerapan Model Pembelajaran Scramble untuk Meningkatkan Hasil Belajar Ipa siswa kelas," Jurnal Pendidikan dan Pengajaran 1, no. 3 (2017): 232-323.

${ }^{4}$ Miftahul Huda, Model-model pengajaran dan pembelajaran (Yogyakarta: Pustaka Pelajar, 2017), 303.
} 
siswa sehinga bisa terapai tujuan penelitian ini adalah untuk meningkatkan hasil belajar siswa pada dalam pembelajaran pendidikan agama Kristen, bukan hanya melalui tes tertulis namun juga meningkatkan hasil belajar siswa selama proses pembelajaran dengan mencapai hasil belajar yang maksimal dan tercapai tujuan pembelajaran lainnya dengan hasil yang baik.

\section{Metode}

Penelitian tindakan kelas merupakan penelitian yang dilakukan untuk meningkatkan atau menyelesaikan keadaan sosial dalam proses pembelajaran serta membantu meningkatkan kinerja guru dalam menyelesaikan masalah yang terjadi di kelas selama proses pembelajaran berlangsung. Dalam penelitian ini menggunakan metode penelitian tindakan kelas (PTK) atau classroom action research artinya penelitian yang dilakukan tentang situasi sosial dengan tujuan meningkatkan kualitas praktik atau pelaksanaan belajar mengajar yang dilakukan dalam situasi konkret atau untuk bisa menyelesaikan masalah yang terjadi selama proses pembelajaran terjadi di kelas. ${ }^{5}$ Penelitian tindakan kelas merupakan salah satu jenis penelitian pendekatana kualitatif deskriptif, meskipun data yang dikumpulkan dapat bersifat kuantitaf. ${ }^{6}$ Peneliti melaksanakan penelitantindakan kelas dengan menerapkan metode scramble dengan tujuan untuk menyelesaikan masalah meningkatkan hasil belajar siswa serta untuk memperbaiki proses belajar yang

${ }^{5}$ Zainal Aqib, Penelitian Tindakan Kelas untuk guru SMP, SMA, SMK (Bandung: Yrama Widya, 2019), 144.

${ }^{6}$ Rochiati Wiriaatmadja, Metode Penelitian Tindakan Kelas (Bandung: Remaja Rosdakarya, 2018), 24-25. sebelumnya, penelitian ini dilakukan dengan dua kali siklus yang mana setiap siklus dilihat dari hasil akhir setiap semester. Subjek penelitian ini adalah Siswa SD Tunas Cemerlang, Jakarta Timur dari kelas 6 dengan jumlah 10 siswa. Sedangkan untuk objek dalam penelitian yang dilakukan adalah metode scramble untuk peningkatan hasil belajar siswa dalam pembelajaran pendidikan agama Kristen.

Dalam pelaksanaan penelitian tindakan kelas ini terdiri dari empat tahap atau langkah yang harus dilakukan dalam setiap siklus selama melakukan penelitian empat langkah itu adalah (1) perencanaan, (2) pelaksanaan, (3) tindakan, (4) terakhir refleksi yang menyangkut analisis dan evaluasi selama proses pelaksanaan penelitian. ${ }^{7}$ Teknik pengumpulan data dalam penelitian ini adalah dengan carates tertulis yang berbentuk soal untuk mengukur pengetahuan anak secara kognitif.Selain itu, teknik pengumpulan data untuk aspek afektif dan psikomotorik dilakukan instrumen non tes untuk mengevaluasi hasil belajar siswa. ${ }^{8}$ Teknik pengumpulan data non tes ini dilakukan melalui observasi yang artinya peneliti berperan sebagai pemerhati atau pengamat dan ikut terlibat secara langsung dalam kegiatan yang diteliti atau diamati. ${ }^{9}$

Data tes yang diperoleh siswa dianalisis secara kualitatif deskriptif yang mana data disajikan dalam bentuk uraian dan pembahasan hasil penelitian. Untuk menghitung persentase hasil belajar siswa klasikal secara kognitif, secara

\footnotetext{
${ }^{7}$ Hidayatullah, Penelitian Tindakan Kelas (Banten: LKP Setia Budi, 2018), 52.

${ }^{8}$ Ranu Iskandar, Pendoman Penilaisan Hasil Belajar Peserta Didik (Sukabumi: Jejak Publisher, 2019), 34.

${ }^{9}$ Wiriaatmadja, Metode Penelitian Tindakan Kelas, 118.
} 
afektif dan psikomotorik dapat dianalisis dengan menggunakan rumus, sebagai berikut: ${ }^{10}$

$$
\mathrm{P}: \underset{\sum \underline{\mathrm{T}} \times 100 \%}{\sum \mathrm{T}_{1}}
$$

Keterangan rumus:

P: ketuntasan belajar yang sesuai dengan KKM sekolah $\geq 75$

$\sum \mathrm{T}$ : jumlah siswa yang memperoleh skor $\geq 75$

$\sum \mathrm{T}_{1}$ : jumlah siswa yangmengikuti tes

\section{Hasil dan Pembahasan}

\section{A. Metode Pembelajaran Scramble}

Dalam proses pembelajaran pendidikan agama Kristen yang menarik dan inovatif penulis memilih menggunakan metode scramble untuk membantu meningkatkan hasil belajar siswa karena metode scramble merupakan metode baru dan jarang digunakan digunakan pada pelajaran pendidikan agama Kristen. Menurut Robert B Taylor metode pembelajaran scramble adalah metode atau cara pembelajaran yang membantu meningkatkan konsentrasi dan kecepatan berpikir siswa dalam proses pembelajaran dan menjawab soal-soal tes. Metode scramble membantu siswa untuk memanfaatkan antara otak kanan dan otak kiri, karena dengan scramble anak bukan hanya menjawab pertanyaan tapi juga menerka dengan cepat jawaban yang tersedia secara acak. ${ }^{11}$ Metode scramble merupakan metode mengajar dengan membagikan lembar soal dan lembar jawaban dan juga ada disediakan lembar jawaban alternative, metode scramble mengajak siswa untuk bisa

\footnotetext{
${ }^{10}$ Sudjana, Penelitian Hasil Belajar Mengajar (Bandung: Remaja Rosdakarya, 2009), 133.

${ }^{11}$ Huda, Model-model pengajaran dan pembelajaran, 303-304.
}

mencari jawaban dengan penyelesaian soal dan menambah wawasan kosakata atau makna kata baru.

Menurut Aris Sohimin metode scramble merupakan metode pembelajaran yang berbentuk permainan dalam bentuk acak kata, kalimat ataupun paragraph yang mana siswa akan dimbimbing untuk mencari jawaban dari kata yang telah di acak. ${ }^{12}$ Metode scramble sering digunakan guru dalam pembelajaran untuk membantu siswa dalam menambah wawasan kosakata. Metode kata scramble yang diartikan dari bahasa Inggris artinya perbuatan pertarungan dan perjuangan, dalam metode scramble ini juga terdapat kolom berisi pertanyaan dan jawaban namun tertulis secara acak, metode scramble mengajak siswa untuk bisa mengerjakan soal dengan cara cepat setiap yang tercepat akan mendapatkan point tertinggi. $^{13}$

Dengan penerapan metode scramble membantu guru untuk memuat siswa lebih konsentrasi dalam menerima pembelajaran. Metode scramble mengajak siswa untuk menemukan jawaba secara acak dari kertas soal dan kertas jawaban yang telah disediakan. Metode scramble memuat siswa perjuang memecahkan soal atau masalah dengan cara cepat serta memberikan siswa hadiah berupa point tertinggi dalam kecepatan menyelesaikan soal atau masalah yang diberikan guru. Metode scramble ini bisa digunakan dalam pembelajaran secara individu dan kelompok. Menurut Nur Ida Lailatul Fitriyah yang telah melakukan penelitian dengan menerapkan metode scramble

\footnotetext{
${ }^{12}$ Aris Sohimin, 68 Metode Pembelajaran Inovatif dalam kurikulum 2013 (Yogyakarta: Ar-Ruzz Media, 2016), 166

${ }^{13}$ Kusnadi, Metode Pembelajaran Klaboratif (Tasikmalaya: Edu Publsher, 2018), 23.
} 
untuk meningkatkan hasil belajar siswa mengatakan bahwa metode scramble membantu siswa untuk lebih mudah memahami suatu materi pelajaran dengan mengenal kata-kata sulit, siswa dilatih untuk lebih kreatif dalam berdiskusi dan menjawab soal, selain itu metode scramble meningkatkan hasil belajar dan kualitas pembelajaran siswa. ${ }^{14}$

Dalam penerapannya metode scramble dimulai dari guru yang menyediakan atau menyajikan topik materi pembelajaran, selanjutnyapendidik akan membagikan lembar kerja disertai lembar jawaban yang telah diacak. Selama lembar kerja dan jawaban yang dibagi guru membri durasi atau batas waktu dalam menyelesaikan soal yang diberi. Setelah waktu yang diberikan habis semua siswa yang selesai atau belum selesai tetap harus mengumpulkan kepada guru, selanjutnya guru akan menilai berapa soal yang telah bisa diselesaikan sesuai dengan waktu, guru juga tidak lupa untuk memberi point setiap soal yang telah diselesaikan secara baik dan benar. ${ }^{15}$ Guru tetap memberi apresiasi dan semangat kepada siswa yang belum bisa menyelesaikan seluruh soal sesuai dengan batas waktu yang diberikan, setiap poin yang di kumpulkan siswa akan di jumlah secara keseluruhan sebagai hasil akhir.

Metode scramble memiliki beberapa kelebihan yaitu: mengajarkan siswa untuk bepikir dengan cara cepat dan tepat, mendorong serta memotivasi

\footnotetext{
${ }^{14}$ Nur Ida Lailatul Fitriyah, "Penerapan Metode Pembelajaran Scramble untuk Meningkatkan Hasil Belajar Siswa pada Mata Pelajaran IPS Kelas V SDN Ketapangkuning," Jurnal Penelitian Pendidikan Guru Sekolah Dasar (JPGSD) 5, no. 3 (2017): 647.

${ }^{15}$ Huda, Model-model pengajaran dan pembelajaran, 304-305.
}

siswa untuk belajar menyelesaikan soal dengan jawaban yang telah diacak, melatih siswa untuk disiplin tepat waktu dalam mengerjakan soal. Akan tetapi, metode scramble juga memiliki kekurangan yang harus diketahui oleh guru yaitu siswa mungkin saja bisa menyontek jawaban teman, siswa hanya menerima bahan pembelajaran secara mentah dan perlu diolah dengan baik. ${ }^{16}$ Meskipun metode scramble memiliki kelebihan dan kelemahan, namun metode scramble bisa di terapkan dalam pembelajaran pendidikan agama Kristen untuk peningkatan hasil belajar siswa, karena metode scramble metode pembelajaran yang baru bagi siswa dan tidak membuat siswa bosan, siswa juga tertantang untuk memecahkan soal dengan cepat dan tepat agar memperoleh skor point tertinggi.

\section{B. Pendidikan Agama Kristen}

Istilah kata pendidikan berasal dari bahasa Inggris "education". Kata "education" dari bahasa Latin yaitu"ducere" yang memiliki arti membimbing (to lead), ditambah awalan "e" yang berarti keluar (out). Jadi kesimpulan makna kata pendidikan yaitu merupakan tindakan yang dilakukan untuk membimbing atau mengajak keluar. ${ }^{17}$ Pendidikan juga dipahami sebagai proses atau langkah perubahan sikap dan perilaku yang dialami olehpribadi atau kelompok yang diusahakan melalui pembelajaran, pengajaran, pelatihan yang melalui berbagai proses, cara, pendidikan agar mampu mendewasakan pribadi seseorang atau kelompok. Pendidikan yang

\footnotetext{
${ }^{16}$ Huda, Model-model pengajaran dan pembelajaran, 306.

${ }^{17}$ Daniel Nuhamara, Pembimbing Pendidikan Agama Kristen (Jakarta: BPK Gunung Mulia, 2010), 8.
} 
diberikan kepada anak dalam upaya meningkatkan aspek pengetahua (kognitif), perubahan sikap (afektif) dan keterampila atau kreatifitas anak (psikomotorik).

\section{Menurut}

Homrighausen

Pendidikan Agama Kristen adalah aktifitas yang berpusat pada persekutuan umat Tuhan.Pendidikan Agama Kristen adalah langkah dan usaha yang dilakukan secara sadar yang membawa seseorang dari suatu keadaan yang baru dan mendidik serta mendewasakan diri dalam sikap yang lebih bertanggung jawab melalui konteks penginjilannya di tengah keluarga, lingkungan, masyarakat.Secara umum pendidikan agama Kristen merupakan usaha sadar yang dilakukan seseorang dengan pencapaian pada kedewasaan iman kepada Yesus Kristus dengan pembinaan Roh Kudus berdasarkan pada Alkitab. ${ }^{18}$ Dengan demikian pendidikan agama Kristen menyadarkan manusia sebagai bait Tuhan yang terlihat dalam kehidupan sehari-hari.

Menurut Demsy Jura memaknai bagiamana pendidikan Kristen yang menjadikan iman sebagai elemen yang sangat penting dan menentukanpribadi setiap orang.Idealnya pendidikan agama Kristen bukan hanya membentuk manusia cerdas dalampemahaman dan mengenal ilmu pengetahuan serta teknologi, melainkan ada upaya cerdas dalam membentuk manusia yang beriman kepada Kristus dalam berpikir serta bertindak sesuai prinsippengajaran iman Kristen.Pendidikan Agama Kristen itu wajib dilakukan oleh semua orang percaya, sebab itu merupakan sebagai wujud nyata dari tanggung jawab iman

\footnotetext{
${ }^{18}$ E.G. dan I.H. Enklaar Homrighausen, Pendidikan Agama Kristen (Jakarta: BPK Gunung Mulia, 2012), 161.
}

Kristen yang diyakininya. ${ }^{19}$ Penulis menyimpulkan pendidikan agama Kristen adalah proses pengajaran yang didasari pada Alkitab serta nilai-nilai Kristiani, pengajaran yang berpusat kepada Kristus dan membutuhkan pada kuasa Roh Kudus untuk membantu serta membimbing setiap pribadi pada semua tingkat pertumbuhan, melalui pengajaran masa kini ke arah pengenalan dan pengalaman pribadi, usaha dalam memperlengkapi mereka untuk pelayanan yang efektif, yang berpusat pada Kristus sang Guru Agung dan perintah yang mendewasakan setiap murid. Pendidikan Agama Kristen juga bukan hanya menyampaikan dan mendidik peserta didik dalam mengenal pengetahuan secara umum, tetapi juga berupaya dalam mendidik pembentukan karakter peserta didik dan pertumbuhan peserta didik secara Rohani.

Pendidikan Agama Kristen disini merujuk pada mata pelajaran Pendidikan Agama Kristen yang diberikan di sekolah. Pendidikan Agama Kristen di sekolah wajib diberikan dan diterima siswa Kristen selama proses pembelajaran berlangsung, karena pendidikan diatur di dalam Undang-Undang Republik Indonesia Nomor 20 Tahun 2003 Tentang Sistem Pendidikan Nasional yang mana di dalam Undang-Undang ini pelaksanaan pendidikan wajib diselenggarakan secara Demokratis dan berkeadilan menjunjung tinggi hak asasi manusia, nilai keagamaan, nilai budaya, kemajemukan bangsa dengan sistematis dengan sistem terbuka dan multimakna. ${ }^{20}$ Pendidikan

\footnotetext{
${ }^{19}$ Demsy Jura, Pendidikan Agama Kristen dalam Rimba Kontemplasi (Jakarta: UKI Press, 2018), 2-18.

${ }^{20}$ Undang-Undang Republik Indonesia Nomor 20 Tahun 2003 tentang Sitem Pendidikan Nasional dan Undang-Undang Republik Indonesia Nomor 14 Tahun 2005 tentang Guru dan Dosen (Jakarta: Transmedia Pustaka, 2008), 1-5.
} 
Agama Kristen di sekolah merupakan kewajiban yang harus dilakukan oleh pengajar yang menyampaikan makna pengajaran Kristen kepada para pelajar melalui situasi lingkungan sekolah.

Pendidikan Agama Kristen di sekolah adalah suatu upaya yang dilakukan pengajar membantu peserta didik menumbuhkan iman Kristen.Pendidikan agama Kristen juga membantu pengajar dalam mendidik peserta didik melalui transformasi kehidupan seutuhnya.Pendidikan Agama Kristen di sekolah menurut Nicolaas Graafland, dia merupakan seorang penginjil dan sekaligus pendidik.Ia berpendapat bahwa pendidikan disekolah sebagai upaya sasaran Injil untuk perubahan masyarakat secara utuh. Graafland mengatakan bagaimana melalui pendidikan peserta didik berubah dan kemudian mampu mengubah masyarakat, oleh karena itu ia mengatakan bahwa sekolah sangat perlu untuk berintegrasi dengan masyarakat, sehingga tidak ada lagi kesenjangan antara yang bersekolah dengan yang tidak sekolah. ${ }^{21}$ Menurut Homrighausen Pendidikan Agama Kristen di sekolah sebagai langkah untuk memberitakan dan mengajarkan pengenalan tentang injil kepada anak-anak yang terkadang sukar untuk dikumpulkan di lingkungan gereja.Pendidikan Agama Kristen di sekolah menyadarkan anak bahwa pendidikan secara umum dan agama bukanlah hal yang bertolak belakang tidak berhubungan, melainkan saling berhubungan dan harus berjalan bersama dan beriringan. Pendidikan Agama Kristen di sekolah mendidik anak-anak untuk menjadi pribadi yang sadar akantanggungjawab dan menjadikan

\footnotetext{
${ }^{21}$ Andar Ismail, Ajarlah Mereka Melakukan (Jakarta: BPK Gunung Mulia, 2004), 153.
}

pendidikan agama sebagai suatu bagian mutlak dan penting yang harus diterima anak-anak. Penyampaian Pendidikan Agama Kristen di sekolah tetaplah harus selaras dengan sekolah dan haruslah tetap berdasarkan kebenaran Firman Tuhan. ${ }^{22}$

Pendidikan Agama Kristen di sekolah bukan hanya pendidikan seperti umumnya yang mengajarkan pada pengetahuan saja, tetapi mencakup segala unsur dalam kehidupan anak yang harus dimiliki setiap pribadi.Pendidikan Agama Kristen mengajarkan anak secara pengetahuan, sosial, spiritual dan membantu dalam pembentukan karakter peserta didik dengan berani mengaplikasikan secara benar dalam kehidupan sehari-hari. $^{23}$ Penulis menyimpulkan Pendidikan Agama Kristen di sekolah adalah pengajaran yang berdasar pada kurikulum serta membentuk karakter siswa yang bukan hanya menyangkit aspek kognitif, afektif, psikomotorik saja melainkan juga pengajaran yang menyangkut aspek spiritual yang mana mengajarkan dan membantu siswa secara rohani, moral untuk menjadi teladan baik dalam kehidupan bersosialisasi di sekolah.

\section{Penerapan Metode Scramble dalam Pembelajaran Pendidikan Agama Kristen}

Guru pada masa sekarang perlu melakukan inovasi dalam pelaksanaan belajar mengajar. Pembelajaran pendidikan agama Kristen tidak terlepas dari penerapan berbagai metode pembelajaran sebagai sarana penyampaian materi kepada siswa.Dalam penerapan metode pembelajaran terutama

\footnotetext{
${ }^{22}$ Homrighausen, Pendidikan Agama Kristen, 168-170.

${ }^{23}$ Michael J. Anthony, Introducing Christian Education, Fondasi Pendidkan Abad 21 (Malang: Gandum Mas, 2017), 500.
} 
bagi guru pendidikan agama Kristen metode pembelajaran yang digunakan haruslah kreatif dan menarik supaya siswa bisa memahami materi pembelajaran dengan baik tidak stress dalam menerima materi dan tidak merasa bosan. Salah satu metode terbaru yang bisa diterapkan atau digunakan guru dalam pembelajaran pendidikan agama Kristen adalah metode scramble.

Pada pembahasan ini penerapan metode scramble untuk pembelajaran pendidikan agama Kristen diterapkan kepada anak kelas 5-6 dalam rentan usia 9 sampai 12 tahun yang mana pada usia ini anak-anak memiliki karakteristik secara mental sangat semangat, menyukai tantangan baru, berpikir tajam, kristis, sudah bisa memahami dan memecahkan suatu masalah yang diberikan oleh guru. ${ }^{24}$

Penggunaan metode scramble dalam pembelajaran pendidikan agama Kristen merupakan pilihan yang baik dalam proses pembelajaran yang menyenangkan, karena metode scramble melibatkan siswa secara aktif serta mengajak siswa untuk bisa berpikir secara cepat dan membuat siswa untuk berusaha memecahkan persoalan yang diberikan. Penerapan metode scramble dalam pembelajaran pendidikan agama kristen membantu siswa untuk memanfaatkan otak kanan dan otak kiri, dalam menerima dan memecahkan materi pembelajaran. $^{25}$

Penerapan metode scramble dalam pendidikan agama Kristen dimulai dengan guru menyajikan materi, salah satu materi pembelajaran agama Kristen dengan penerapan metode scramble ialah

\footnotetext{
${ }^{24}$ Paulus Lilik Kristianto, Prinsip dan Praktik Pendidikan Agama Kristen (Yogyakarta: ANDI, 2012), 92.

${ }^{25}$ Huda, Model-model pengajaran dan pembelajaran, 304.
}

tentang hidup melayani. Dalam penyajian materi agama Kristen yang disampaikan kepada siswa guru telah menyediakan soal beserta dengan lembar jawaban yang disusun secara acak. Penerapan metode scramble ini akan terasa menyenangkan karena siswa diajak untuk aktif dalam menyelesaikan soal dengan jawaban yang di acak, serta point tambahan yang akan diperoleh siswa setelah menyelesaikan pertanyaan sesuai dengan batas waktu yang telah ditentukan guru. Setelah siswa menyelesaikan soal yang diberikan guru akan menilai setiap soal yang benar akan diberikan point dan point tambahan untuk siswa yang mampu menyelesaikan seluruh soal dengan tepat waktu. Dalam pemberian point atau nilai ini guru akan mengumpulkan setiap nilai yang diperoleh siswa secara individu dan akan di gabungkan secara keseluruhan sebagai tambahan nilai untuk hasil belajar siswa dalam pembelajaran pendidikan agama Kristen.

Melalui penerapan metode scramble dalam pembelajaran pendidikan agama Kristen membuat siswa merasakan belajar sambil bermain, siswa dapat berkreasi, belajar, berpikir, mempelajari dengan santai tidak membuat siswa stress, bosan, meningkatkan kosakata yang baru diketahui serta membuat siswa berpikir secara kritis dan memperoleh point nilai tambahan dalam pembelajaran agama Kristen.

\section{Hasil Belajar Siswa}

Hasil belajar yang berasal dari dua kata hasil dan belajar yang memiliki arti kata yang berbeda.Kata hasil memiliki arti sebagai capaian dari suatu aktivits yang telah dilaksanakan, baik yang dilakukan individu maupun dalam kelompok. Sedangkan pengertian belajar adalah cara atau usaha yang dilakukan 
oleh seseorang untuk memproleh perubahan baik secara keseluruhan hal ini diperoleh melalui pengalaman pribadi dan interaksi dengan lingkungan sekitar. ${ }^{26}$ Dengan demikian hasil belajar dapat disimpulkan sebagai pencapaian, gambaran kemampuan siswa yang diperoleh dari perubahan, penilaian selama proses belajar siswa atau hasil belajar bisa dibilang sebagai prestasi yang dicapai anak berupa nilai dalam mata pelajaran.

Toto Sugiarto dalam buku ELearning berbasis Schoology mengutip pendapat Arikunto yang menjelaskan hasil belajar adalah usaha yang dicapai seseorang setelah menyelesaiakan rangkaian proses belajar atau pembelajaran dengan terlebih dahulu melakukan evaluasi dari usaha belajar yang dilakukan, hasil belajar dapat diperoleh dengan melakukan tes tertulis, tugas harian, tes secara lisan selama proses pembelajaran berlangsung. Pengertian hasil belajar lainnya menjelaskan dalam hasil belajar mencakup tiga unsuratau aspek penting yaitu aspek kemampuan kognitif, afektif dan psikomotori. ${ }^{27}$ Mengutip pendapat Sudjana juga memaparkan pengertian hasil belajar sebagai dasar perubahan tingkah laku siswa, yang mencakup bidang kognitif, afektif dan psikomotorik. ${ }^{28}$ Dengan demikiandapat disimpulkan hasil belajar merupakan pencapaian dan perubahan yang diterima seseorang setelah melakukan kegiatan pembelajaran dengan mengikuti berbagai

\footnotetext{
${ }^{26}$ Syafaruddin, Supiono, dan Burhanuddin, Guru Mari Kita Menulis Penelitian Tindakan Kelas (PTK) (Yogyakarta: Budi Utama, 2019), 79.

${ }^{27}$ Toto Sugiarto, E-Learning Berbasis Schoology Tingkatkan Hasil Belajar Fisika (Cv. Mine, 2020), 5-6.

${ }^{28}$ Syahputra, Snowbal Throwing Tingkatkan Minat dan Hasil Belajar, 24.
}

tes yang terdiri atas aspek secara kognitif, afektif, psikomototik dan hasil yang dicapai sesuai dengan standar kriteria ketuntasan dalam pembelajaran.

Mengutip pendapat Djamarah ada tiga kelompok faktor yang mempengaruhi hasil belajar.Faktor pertama stimulus artinya segala hal yang ada di luar individu atau pribadi seorang seperti pengaruh lingkungan yang membantu perubahan yang diterima. Faktor kedua metode mengajar artinya metode atau cara mengajar menyampaikan bahan ajar yang pendidik lakukan sangat mempengaruhi cara belajar siswa, dengan kata lain metode yang baik, jelas, inovatif, kreatif yang dilakukan guru dalam menyempaikan materi ajar sangat mempengaruhi siswa untuk memperoleh hasil belajar secara baik dan efektif, karena metode merupakan salah satu alat untuk mencapai tujuan pembelajaran yaitu hasil belajar siswa yang sesuai dengan kriteria kelulusan. Faktor ketiga individu artinya faktor individu atau diri sendiri sangat memiliki pengaruh penting pada kegiatan belajar siswa dalam mencapai hasil belajar, pertumbuhan, perkembangan, kemandirian, kesiapan dan kematangan siswa dalam menerima pembelajaran yang berasal dari diri sendiri akan membantu siswa untuk lebih fokus mencapai hasil belajar yang terbaik. ${ }^{29}$ Dengan demikian proses belajar mengajar tidak terlepas dari lingkungan sekitar baik itu keluarga, guru dan dari diri sendiri yang bekerjasama untuk menciptakan lingkungan belajar yang baik sehingga siswa mampu mencapai hasil belajar maksimal selama proses pembelajaran dan mencapai tujuan pendidikan yang mana pada dasarnya

\footnotetext{
${ }^{29}$ Syafaruddin, Supiono, dan Burhanuddin, Guru Mari Kita Menulis Penelitian Tindakan Kelas (PTK), 80.
} 
merupakan usaha dalam pembentukan tingkah laku, yang mencakup secara intelektual, moral maupun sosial.

\section{Hasil Penelitian}

Hasil pada penelitian dalam siklus

I dan II diperoleh dengan adanya peningkatan hasil belajar siswa dalam pembelajaran pendidikan agama Kristen secara kognitif, afektif dan psikmotorik dengan menggunakan metode belajar scramble, sebagai berikut :

\begin{tabular}{|c|l|c|c|c|}
\hline No. & Nama & Kkm & Siklus I & Siklus II \\
\hline 1 & Justin & 75 & 80 & 79 \\
\hline 2 & Jion & 75 & 78 & 80 \\
\hline 3 & Tania & 75 & 65 & 70 \\
\hline 4 & Keiko & 75 & 65 & 73 \\
\hline 5 & Steven & 75 & 70 & 75 \\
\hline 6 & Claudia & 75 & 82 & 80 \\
\hline 7 & Marfel & 75 & 85 & 86 \\
\hline 8 & Ricky & 75 & 70 & 78 \\
\hline 9 & Chris & 75 & 83 & 85 \\
\hline 10 & Yohana & 75 & 69 & 75 \\
\hline Total keseluruhan & $\mathbf{7 4 7}$ & $\mathbf{7 8 2}$ \\
\hline \multicolumn{2}{|l|}{ Jata-rata nilai } & $\mathbf{7 4 , 7}$ & $\mathbf{7 8 , 2}$ \\
\hline \multicolumn{2}{|l}{ Jumlah yang tuntas yang tidak tuntas } & $\mathbf{5}$ & $\mathbf{8}$ \\
\hline
\end{tabular}

Tabel 1. Tabel penilaian hasil belajar siswa dalam 2 siklus selamat satu tahun pembelajaran.

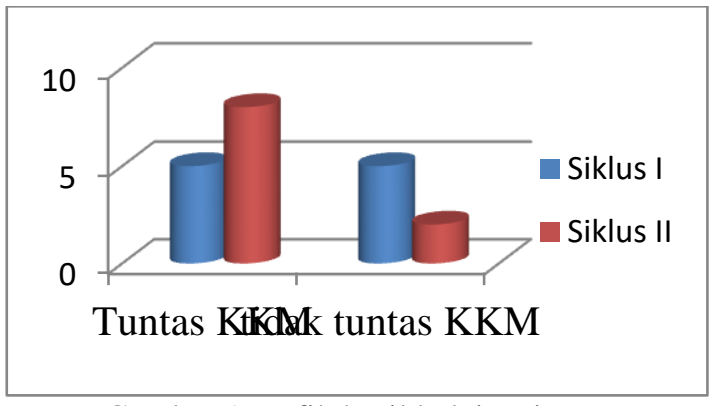

Gambar 1.grafik hasil belajar siswa.

\begin{tabular}{|c|c|c|}
\hline $\begin{array}{c}\text { Persentase } \\
\text { sesuai } \\
\text { KKM }\end{array}$ & Siklus I & Siklus II \\
\cline { 2 - 3 } & $50 \%$ & $80 \%$ \\
\hline
\end{tabular}

Tabel 2. Persentasi ketuntasan hasil belajar secara klasikal.

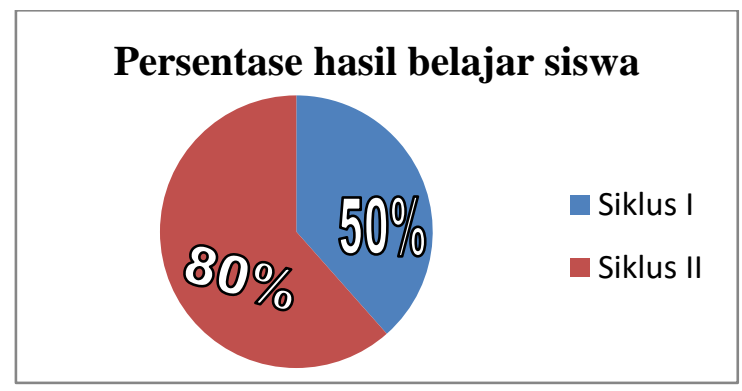

Gambar 2. Persentase peningkatan hasil belajar siswa.

Dengan tabel di atas terlihat pada siklus I persentase ketuntasan hasil belajar siswa hanya tercapai $50 \%$ atau setengah dari siswa memperoleh hasil belajar diatas kriteria ketuntasan (KKM) sedangkan setengah dari siswa lainnya masih belum memperoleh hasil belajar yang memuaskan. Dengan perbaikan metode scramble yang penulis lakukan selama masa pembelajaran dalam siklus 
II diapat hasil peningkatan $80 \%$ siswa mencapai ketuntasan hasil belajar yang baik. Selama melakukan pembelajaran penulis menerapkan metode scramble meskipun dalam siklus I hanya setengah siswa mampu mencapai kebuntasan hasi belajar yang disebabkan siswa masih kurang memahami cara kerja dari metode scramble yang baru dikenal. Selama siklus II peneliti melakukan perbaikan dalam menerapkan metode scramble dengan penambahan setiap point dan tetap memberikan point kepada siswa yang menyelesaikan meskipun telat dari waktu yang ditentukan, sehingga siswa masih tetap memiliki point akhir.

\section{Kesimpulan}

Berdasarkan hasil penelitan di SD Tunas Cemerlang, Jakarta Timur dapat disimpulkan dengan penerapan metode scramble dalam pembelajaran pendidikan agama Kristen di sekolah memberikan dampak positif dalam meningkatkan hasil belajar siswa khususnya dalam pembelajaran pendidikan agama Kristen.Dalam siklus I dan siklus II terlihat ada peningkatan persentase hasil belajar siswa dalam mata pelajaran pendidikan agama Kristen. Selain itu penerapan metode scramble dalam proses pembelajaran pendidikan agama Kristen membuat pelaksanaankegiatan belajarpendidik dan siswa menjadi lebih menyenangkan, metode pembelajaran terbaru membantu guru menyampaikan materi dengan baik dan tidak membosankan. Metode scramble yang diterapkan dalam pendidikan agama Kristen memberikan keuntungan bagi siswa yaitu membuat siswa menerima pembelajaran dengan menyenangkan, menambah wawasan kosakata dalam pelajaran agama kristen, membantu siswa dalam cepat menyelesaikan soal dan memberikan siswa point tambahan sebagai nilai hasil akhir untuk mata pelajaran. Selain itu, Metode scramble membantu guru meningkatkan hasil belajar siswa, mnciptakan proses pembelajaran agama Kristen yang menyenangkan sehingga nilai-nilai rohani dapat tersampaikan dan diterima dengan baik oleh siswa, metode scramble juga memberikan keuntungan bagi guru yaitu membantu guru mencapai tujuan dari pembelajaran dan membuat guru lebih kreatif dalam menyampaikan materi mempelajaran melalui berbagai cara atau metode pembelajaran.

\section{Referensi}

Anthony, Michael J. Introducing Christian Education, Fondasi Pendidkan Abad 21. Malang: Gandum Mas, 2017.

Aqib, Zainal. Penelitian Tindakan Kelas untuk guru SMP, SMA, SMK. Bandung: Yrama Widya, 2019.

Fitriyah, Nur Ida Lailatul. "Penerapan Metode Pembelajaran Scramble untuk Meningkatkan Hasil Belajar Siswa pada Mata Pelajaran IPS Kelas V SDN Ketapangkuning." Jurnal Penelitian Pendidikan Guru Sekolah Dasar (JPGSD) 5, no. 3 (2017): 647.

Herdiawanto, Heri, Fokky Fuad Wasitaatmadja, dan Jumanta Hamdayama. Kewarganegaraan dan Masyarakat Madani. Jakarta: Prenadamedia Group, 2019.

Hidayatullah. Penelitian Tindakan Kelas. Banten: LKP Setia Budi, 2018.

Homrighausen, E.G. dan I.H. Enklaar. Pendidikan Agama Kristen. Jakarta: BPK Gunung Mulia, 2012. 
Huda, Miftahul. Model-model pengajaran dan pembelajaran. Yogyakarta: Pustaka Pelajar, 2017.

Iskandar, Ranu. Pendoman Penilaisan Hasil Belajar Peserta Didik. Sukabumi: Jejak Publisher, 2019.

Ismail, Andar. Ajarlah Mereka Melakukan. Jakarta: BPK Gunung Mulia, 2004.

Jura, Demsy. Pendidikan Agama Kristen dalam Rimba Kontemplasi. Jakarta: UKI Press, 2018.

Kristianto, Paulus Lilik. Prinsip dan Praktik Pendidikan Agama Kristen. Yogyakarta: ANDI, 2012.

Kusnadi. Metode Pembelajaran Klaboratif. Tasikmalaya: Edu Publsher, 2018.

Nuhamara, Daniel. Pembimbing Pendidikan Agama Kristen. Jakarta: BPK Gunung Mulia, 2010.

Saridewi, N.M. Putri, dan N.Nym. Kusmariyatni. "Penerapan Model Pembelajaran Scramble untuk Meningkatkan Hasil Belajar Ipa siswa kelas." Jurnal Pendidikan dan Pengajaran 1, no. 3 (2017): 232323.

Sohimin, Aris. 68 Metode Pembelajaran Inovatif dalam kurikulum 2013. Yogyakarta: Ar-Ruzz Media, 2016.

Sudjana. Penelitian Hasil Belajar Mengajar. Bandung: Remaja Rosdakarya, 2009.

Sugiarto, Toto. E-Learning Berbasis Schoology Tingkatkan Hasil Belajar Fisika. Cv. Mine, 2020.

Syafaruddin, Supiono, dan Burhanuddin. Guru Mari Kita Menulis Penelitian Tindakan Kelas (PTK). Yogyakarta: Budi Utama, 2019.
Syahputra, Edy. Snowbal Throwing Tingkatkan Minat dan Hasil Belajar. Sukabumi: Haura Publising, 2020.

Undang-Undang Republik Indonesia Nomor 20 Tahun 2003 tentang Sitem Pendidikan Nasional dan Undang-Undang Republik Indonesia Nomor 14 Tahun 2005 tentang Guru dan Dosen. Jakarta: Transmedia Pustaka, 2008.

Wiriaatmadja, Rochiati. Metode Penelitian Tindakan Kelas. Bandung: Remaja Rosdakarya, 2018. 
Jurnal Shanan

Volume 5 Nomor 1 Maret 2021 hal. 15-28
ISSN. 2722-4678 (Online)

ISSN: 2549-8061 (Print) 